\title{
PENGARUH LAMA JAM KERJA PADA IBU BEKERJA TERHADAP PEMBERIAN ASI EKSKLUSIF
}

\author{
Sri Wulan Ratna Dewi, Vira Ainun Nisa, Neli Sunarni, Rosidah Solihah \\ STIKes Muhammadiyah Ciamis \\ (sriwulanratnadewi@gmail.com)
}

\begin{abstract}
ABSTRAK
ASI Eksklusif (menurut WHO) adalah pemberian ASI saja pada bayi sampai usia 6 bulan tanpa tambahan cairan ataupun makanan lain. ASI Eksklusif adalah pemberian hanya ASI saja tanpa makanan dan minuman lain. ASI Eksklusif dianjurkan sampai 6 bulan pertama kehidupan (Depkes RI, 2005). Latar belakang : Pemberian ASI di Indonesia belum dilaksanakan sepenuhnya dan masih sangat rendahnya pemberian ASI eksklusif terutama pada ibu bekerja. Dari hasil observasi yang dilakukan oleh peneliti di peroleh data bahwa 8 dari 10 ibu bekerja yang menyusui (bayi umur 6-12 bulan) tidak memberikan ASI eksklusif pada bayinya, dan 9 dari 10 ibu tidak bekerja yang menyusui (bayi umur 6-12 bulan) memberikan ASI eksklusif pada bayinya. Tujuan : Untuk mengetahui hubungan status pekerjaan terhadap pemberian ASI eksklusif. Metode : jenis penelitian ini adalah analitik dengan pendekatan Cross Sectional, dengan status pekerjaan sebagai variabel independen dan pemberian ASI eksklusif sebagai variabel dependen, menggunakan 21 sampel. Hasil : penelitian ini dilakukan dengan menggunakan metode kuantitatif yaitu dengan menyebarkan formulir berupa g-form sehingga dapat disimpulkan ada hubungan antara lama jam kerja pada ibu bekerja dengan pemberian ASI ekslusif. Simpulan : ada hubungan antara lama jam kerja pada ibu bekerja dengan pemberian ASI eksklusif.
\end{abstract}

\section{Kata kunci : Lama jam kerja, Ibu Bekerja, ASI Eksklusif}

\section{ABSTRACT}

Exclusive breastfeeding (according to WHO) is breastfeeding only for infants up to 6 months of age without additional fluids or other foods. Exclusive breastfeeding is giving only breast milk without other food and drinks. Exclusive breastfeeding is recommended for the first 6 months of life (WHO, 2005). Background: Breastfeeding in Indonesia has not been fully implemented and there is still very low level of exclusive breastfeeding, especially for working mothers. From the results of observations made by researchers, data was obtained that 8 out of 10 working mothers who breastfeed (babies aged 6-12 months) do not exclusively breastfeed their babies, and 9 out of 10 non-working mothers who breastfeed (babies aged 6-12 months) giving exclusive breastfeeding to the baby. Purpose: To determine the relationship between employment status and exclusive breastfeeding. Methods: This type of research is analytic with a cross sectional approach, with job status as the independent variable and exclusive breastfeeding as the dependent variable, using 21 samples. Result: This research was conducted using quantitative methods, namely by distributing a form in the form of a $g$-form so that it can be concluded that there is a relationship between long working hours for working mothers and exclusive breastfeeding. Conclusion: there is a relationship between work status and exclusive breastfeeding.

Keywords: Long Working Hours, Working Mother, Exclusive Breastfeeding

\section{PENDAHULUAN}

World Health Organization (WHO)

dan United Nations International Children's

(UNICEF) dalam Global Strategy for Infant and Young Child Feeding mengatur pola pemberian makan terbaik pada bayi dari lahir sampai usia dua tahun untuk meningkatkan kualitas kesehatan pada bayi 
dan anak dengan cara memberikan air susu ibu (ASI) kepada bayi segera dalam waktu satu jam setelah bayi lahir, memberikan ASI saja atau pemberian ASI secara eksklusif sejak lahir sampai bayi berusia 6 (enam) bulan, memberikan makanan pendamping air susu ibu (MPASI) sejak bayi berusia 6 (enam) bulan sampai 24 bulan serta meneruskan pemberian ASI sampai anak berusia 24 bulan atau lebih. (1) Pemberian ASI eksklusif berpengaruh pada kualitas kesehatan bayi. Semakin sedikit jumlah bayi yang mendapat ASI eksklusif, maka kualitas kesehatan bayi dan anak balita akan semakin buruk, karena pemberian makanan pendamping ASI yang tidak benar menyebabkan gangguan pencernaan yang selanjutnya menyebabkan gangguan pertumbuhan, yang pada akhirnya dapat meningkatkan angka kematian bayi (AKB) Peran perempuan dalam dunia kerja tidak dapat diabaikan. Tren jumlah angkatan kerja perempuan dari tahun 2012 sampai dengan 2014 menunjukkan adanya peningkatan. Berdasar data Kementerian Tenaga Kerja dan Transmigrasi pada 2014 jumlah angkatan kerja perempuan yang terdiri dari golongan umur 15 Kementerian Tenaga Kerja dan Transmigrasi pada 2014 jumlah angkatan kerja pere. Sementara itu, sebesar 66 persen angkatan kerja perempuan tersebut berada dalam usia reproduksi. usia reproduksi seseorang berada dalam rentang usia 1515 berada Usia reproduksi dalam hal ini mengacu pada kemampuan seorang perempuan dalam menghasilkan keturunannya. Jumlah angkatan kerja perempuan yang cukup besar pada usia reproduksi memungkinkan pekerja perempuan tersebut dapat mengandung serta memiliki anak. (2). Pemberian ASI eksklusif berpengaruh padakualitas kesehatan bayi. Semakin sedikit jumlah bayi yang mendapat ASI eksklusif, maka kualitas kesehatan bayi dan anak balita akan semakin buruk, karena pemberian makanan pendamping ASI yang tidak benar menyebabkan gangguan pencernaan yang selanjutnya menyebabkan gangguan pertumbuhan, yang pada akhirnya dapat meningkatkan angka kematian bayi. (3)

\section{METODE}

Jenis penelitian ini adalah analitik dengan pendekatan Cross Sectional, dengan status lama jam kerja sebagai variabel independen dan pemberian ASI eksklusif sebagai variabel dependen, menggunakan 21 sampel. Populasi dalam penelitian ini adalah ibu yang mempunyai bayi usia 6-12 bulan yang memberikan makanan pendamping ASI.

\section{PEMBAHASAN}

Tabel 1 respon pertanyaan apakah ibu memberikan ASI eksklusif?

\begin{tabular}{|lcc|}
\hline Respon & Frequency & Cumulative percent \\
\hline Ya & 15 & 88.2 \\
Tidak & 2 & 11.8 \\
\hline Total & 17 & 100 \\
\hline
\end{tabular}


Dari tabel ini mendapatkan hasil yaitu $88,2 \%$ reponden menjawab ya dan $11.8 \%$ nya menjawab tidak. Pertanyaan tersebut yang peneliti tanyakan yaitu apakah responden selalu memberikan ASI.

Tabel 2 respon pertanyaan Berapa lama kah ibu meninggalkan bayi ketika bekerja ?

\begin{tabular}{|lcc|}
\hline Respon Frequency & Cumulative percent \\
\hline 2 Jam & 2 & 11.8 \\
3 jam & 1 & 5.9 \\
4 jam & 1 & 5.9 \\
5 jam & 1 & 5.9 \\
6 jam & 4 & 23.5 \\
7 jam & 1 & 5.9 \\
8 jam & 7 & 41.2 \\
\hline Total & 17 & 100 \\
\hline
\end{tabular}

Jawaban paling banyak yaitu 8 jam jadi seharusnya jam kerja di Indonesia untuk ibu bekerja harus lebih di kurangi supaya ibu bekerja yang menyusui bisa memberikan ASI terhadap bayinya.Tingkat pemberian ASI eksklusif yangrendah tentunya akan mempengaruhipertumbuhan bayi, karena di dalam ASI banyak sekali zat-zat yang terkandung didalamnya sebagai asupan yang terbaik bagi bayi. tidak ada makanan lainnya yang mampu menyaingi kandungan gizinya. ASI Ekslusif atau lebih tepat pemberian ASI secara ekslusif adalah bayi hanya diberi ASI saja, tanpa tambahan cairan lain seperti susu formula, jeruk, madu, air teh, air putih, dan tanpa tambahan makanan padat seperti pisang, pepaya, bubur susu, biskuit, bubur nasi, dan tim. Pemberian ASI secara eksluisif ini dianjurkan untuk jangka waktu setidaknya selama 6 bulan (4) . Masalah kesehatan anak di Indonesia dipengaruhi oleh tingginya angka kematian bayi (AKB). Tingginya angka kematian bayi di Indonesia disebabkan oleh kelahiran prematur, infeksi saat kelahiran, rendahnya gizi saat kelahiran, kelainan bawaan (kongenital) serta rendahnya pemberian ASI segera setelah bayi lahir (inisiasi ASI) dan pemberian ASI eksklusif selama 6 bulan pertama kehidupan bayi. (5). Hasil penelitian ini sesuai dengan teori yang menyatakan bahwa banyak ibu tidak menyusui secara eksklusif dikarenakan ASI tidak cukup, ibu bekerja dengan cuti hamil tiga bulan, jam kerja, dan takut ditinggal suami (6). Menyusui merupakan hak dan kewajiban bagi ibu dan bayi. Perlu adanya dukungan dan motivasi dari berbagai pihak, antara lain dari keluarga, masyarakat, dan tenaga kesehatan, agar dapat dilaksanakan secara optimal. Memberikan ASI kepada bayi, bukan saja memberikan kebaikan bagi bayi tapi juga keuntungan untuk ibu. Banyak manfaat yang bisa diperoleh bagi ibu maupun bayinya dengan pemberian ASI khususnya ASI eksklusif. Keunggulan ASI adalah terdapat lebih dari 100 jenis zat gizi yang tidak terdapat dalam susu sapi yang diperlukan untuk pertumbuhan dan perkembangan kecerdasan anak. Sedangkan bagi ibu dapat menurunkan resiko perdarahan dan anemia serta Amenunda terjadinya kehamilan berikutnya. (3). Masalah ibu bekerja yang baru saja melahirkan adalah merasa berat ketika 
akan meninggalkan bayinya untuk bekerja kembali ketika masa cuti telah selesai sementara ASI menjadi kebutuhan utama bagi bayi. Anjuran untuk bayi lahir adalah mendapatkan ASI eksklusif selama enam bulan kemudian diteruskan sampai usia 2 tahun sementara masa cuti melahirkan umumnya hanyalah tiga bulan. Pada ibu yang bekerja pemberian ASI terhambat pada waktu untuk menyusui karena intensitas pertemuan antara ibu dan anak yang kadang kurang.(7)

\section{KESIMPULAN DAN SARAN}

Sebagian besar ibu yang memiliki status pekerjaan bekerja $(88,2 \%)$ meninggalkan bayinya bekerja selama 8 jam jadi tidak memberikan ASI eksklusif dan $(5,9 \%)$ ibu yang meninggalkan bayinya bekerja selama 3 jam pasti memberikan ASI eksklusif. Ada hubungan antara status pekerjaan ibu dengan pemberian ASI.

\section{DAFTAR PUSTAKA}

1. Agustia N, Machmud R, Usman E. Faktor yang Berhubungan dengan Pemberian ASI Eksklusif pada Ibu Bekerja di Kabupaten Ogan Komering Ulu. J Kesehat Andalas. 2019;8(3):573.

2. Dahlan A, Mubin F, Mustika DN. Hubungan Status Pekerjaan dengan Pemberian ASI Eksklusif di Kelurahan Palebon

3. Listyaningrum TU, Vidayanti V. Tingkat Pengetahuan dan Motivasi Ibu Berhubungan dengan Pemberian ASI
Eksklusif pada Ibu Bekerja. J Ners dan Kebidanan Indones. 2016;4(2):55.

4. Maulida H, Afifah E, Pitta Sari D. Tingkat Ekonomi dan Motivasi Ibu dalam Pemberian ASI Eksklusif pada Bayi Usia 0-6 Bulan di Bidan Praktek Swasta (BPS) Ummi Latifah Argomulyo, Sedayu Yogyakarta. J Ners dan Kebidanan Indones. 2016;3(2):116.

5. Puspitasari S, Pujiastuti W, Sit S, Kes M. Hubungan Pemberian Asi Eksklusif Terhadap Status Gizipada Bayi Usia 7-8 Bulan Di Wilayah Puskesmas Tlogomulyo,Kabupaten Temanggung Tahun 2014. Kebidanan. 2015;4(8):629.

6. Rahadian AS. Fulfilling The Right For Exclusife Breastfeeding Among Working Women: Opportunities And Challengs. J Kependud Indones. 2014;9 No.2(November):109-18.

7. Wulandari A. Susu Ibu Perah (Asip) Dengan Praktik Pemberian Asip Pada Ibu Bekerja Di Kelurahan Tandang Kecamatan Tembalang Kota Semarang. J ... [Internet]. 2013; Available from: https://immar razy.unimus.ac.id/ojsunimu s/index.php/ jur_bid/article/view/102 